\title{
骨芽細胞分化を標的とした新規経口骨粗鬆症治療薬の開発
}

\author{
北尾達哉, * 伊東佑真, 福井正樹, 山本めぐみ, \\ 庄子幸倫，武田滋充，白波瀬弘明
}

\section{A Novel Oral Anti-osteoporosis Drug with Osteogenesis-promoting Effects via Osteoblast Differentiation}

\author{
Tatsuya Kitao, ${ }^{*}$ Yuma Ito, Masaki Fukui, Megumi Yamamoto, \\ Yoshimichi Shoji, Shigemitsu Takeda, and Hiroaki Shirahase \\ Kyoto Pharmaceutical Industries, Ltd.; 38 Nishinokyo Tsukinowa-cho, Nakagyo-ku, Kyoto 604-8444, Japan.
}

(Received July 10, 2018)

\begin{abstract}
Osteoporosis increases the risk of bone fractures (e.g., the femur), reduces a person's activities of daily living (ADL) and increases the likelihood of being bedridden. Therapeutic drugs for osteoporosis include oral bisphosphonates and intravenous receptor activator of nuclear factor- $\kappa$ B ligand (RANKL) antibodies, both of which suppress osteoclast activity, as well as the subcutaneously administered recombinant human parathyroid hormone (PTH), which activates osteoblasts. However, there is currently no oral osteogenesis-promoting drug. In the present study, we found a low-molecular-weight compound, KY-273, with osteogenesis promoting effects. KY-273 induced osteoblast differentiation in ST2 cells and in rat bone marrow-derived mesenchymal stem cells at a dose of $0.1 \mu \mathrm{M}$. On the other hand, KY-273 did not clearly exert differentiation effects in osteoclasts, chondrocytes, adipocytes, or myoblasts. In ovariectomized rats, KY-273 clearly increased serum bone alkaline phosphatase (ALP) by at a dose of $3 \mathrm{mg} / \mathrm{kg}$ for 8 weeks, and increased both the cortical bone volume and medullary volume of the diaphyseal and epiphyseal regions of femoral bone, but did not affect trabecular bone. Although alendronate (used to decrease bone loss) increased trabecular bone, it did not have any significant effects on cortical bone. PTH increased epiphysis cortical and trabecular bone volume, and reduced medullary volume. KY-273 also displayed good oral absorption in rats. In conclusion, KY-273 is a promising candidate for use as an oral anti-osteoporosis drug with osteogenesis promoting effects.
\end{abstract}

Key words_ osteoporosis; osteoblast differentiation; cyclin-dependent kinase 8

\section{1. はじめに}

骨粗鬆症は，WHO によれば，「低骨量と骨組織 の微細構造の異常を特徵とし, 骨の脆弱性が増大 し，骨折の危険性が増大する疾患」と定義されてい る. 1) 原発性骨粗鬆症は, 高齢者, 特に閉経後の女 性に好発し，転倒などのわずかな衝撃で容易に骨折 し, 生活の質（QOL）及び日常生活動作（activities of daily living; ADL) 低下を来たすとともに, 死亡リスクを上昇させるため, 社会的に大きな問題 となっている. 近年, 人口の高齢化に伴い骨粗鬆症 患者数は増加の一途を辿り，国内の患者数は約

京都薬品工業株式会社（干604-8444 京都市中京区西ノ 京月輪町 38)

*e-mail: t-kitao@kyoto-pharm.co.jp

本総説は, 日本薬学会第 138 年会シンポジウムS50 で

発表した内容を中心に記述したものである.
1300 万人, 日米欧では 7500 万人以上と推定されて いる. 2)

現在, 骨粗鬆症の治療には, 経口剂としてビスホ スホネート製剤のアレンドロネートやリセドロネー 卜等, 選択的エストロゲン受容体モジュレーター (selective estrogen receptor modulator; SERM) のラ ロキシフェンやバゼドキシフェンが, 注射剤として parathyroid hormone (PTH) 製剤のテリパラチド, 抗 receptor activator of nuclear factor- $\kappa \mathrm{B}$ ligand (RANKL) 抗体のデノスマブなどが用いられてい るが, 3-5) かならずしも十分ではない. より治療効 果及び安全性に優れた新たな経口治療薬の開発が望 まれている。

\section{2. 骨リモデリングと骨粗鬆症治療薬}

骨組織は，骨リモデリングすなわち恒常的に骨吸 収と骨形成を繰り返すことにより，骨量・骨強度・ 


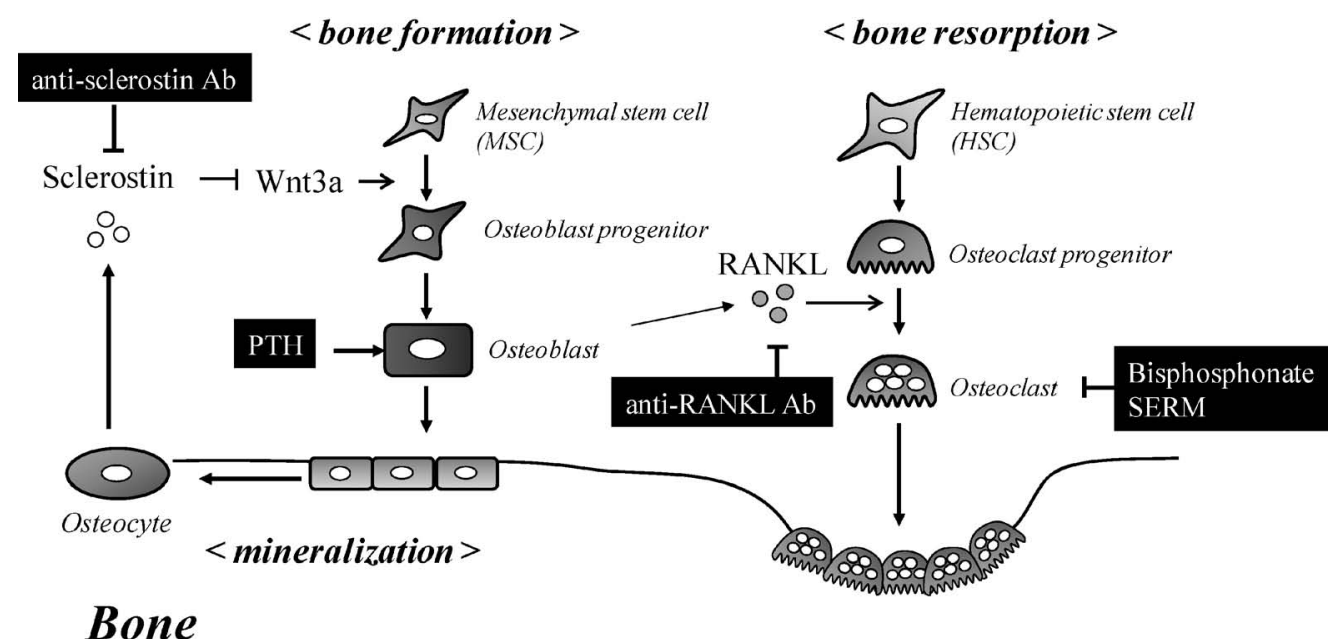

Fig. 1. Bone Remodeling and Anti-osteoporosis Drugs

骨弾力性を維持している (Fig. 1). $\left.{ }^{6}\right)$ 骨吸収では, 造血幹細胞が前駆破骨細胞を経て，破骨細胞に分化 し，骨細胞を吸収する。一方，骨形成では，間葉系 幹細胞が骨芽細胞を経て，骨細胞に分化する. ${ }^{7)}$ 骨 芽細胞，破骨細胞，骨細胞は複雑なクロストークを 介し，骨形成・骨吸収バランスを精妙に調節してい る。例えば，骨芽細胞や骨細胞が分泌する RANKL により造血幹細胞から破骨細胞への分化が誘導され て骨吸収が生じ，そこに新たな骨芽細胞が遊走し骨 細胞が形成される。 Wnt3a は, 間葉系幹細胞から 前駆骨芽細胞への分化を促進し，骨細胞が分泌する スクレロスチンが Wnt3a の作用を抑制的に調節す る.これらの調節機構の破綻による骨形成・骨吸収 バランスの異常が, 骨量・骨強度・骨弾力性減少を 来たすと考えられている.

したがって，骨吸収阻害剂及び骨形成促進剂は， 骨リモデリングの異常を是正することにより骨粗鬆 症治療作用を示すと考えられる。経口骨吸収阻害剤 として繁用されているビスホスホネート類は破骨細 胞に作用し，骨吸収を阻害する。注射薬の抗 RANKL 抗体デノスマブは破骨細胞の分化を抑制す る。しかし，これらの強力な骨吸収抑制薬は，長期 使用により骨代謝の過剩抑制を来たし，顎骨壊死や 大腿骨非定形骨折リスク上昇などの副作用が問題と なっている. ${ }^{8)}$ 骨形成促進剂では, 注射薬の PTH が間歇投与により骨芽細胞に作用し，骨形成を促進 する．新たな注射用骨形成促進剂として抗スクロレ スチン抗体が開発されているが，上市には至ってい ない，抗スクロレスチン抗体は著明な骨形成促進作

用を示すが，心血管系副作用が懸念されている. ${ }^{9}$

このような現状から, 抗体より安価で, 服用が容 易な，経口用骨形成促進剤の開発が待望されている が，いまだ開発に成功したものはない.

\section{3. 骨芽細胞分化促進薬の創製}

新たな骨形成促進薬として，骨芽細胞分化を促進 し，経口投与可能な低分子化合物の創製を目指し た。これまでに知られている骨形成促進化合物の基 本構造をヒントに，約 1000 化合物を設計・合成 し, マウス間葉系幹細胞株であるST2 細胞を用い て骨芽細胞分化促進作用を検討した（Fig. 2)。す なわち, ST2 細胞をアスコルビン酸含有培地で 4 日 間培養し, 骨芽細胞マーカー酵素であるアルカリ フォスファターゼ (alkaline phosphatase; ALP) 活 性に対する効果を検討した。ついで，16 日間培養 し，石灰化作用に対する効果を検討した，優れた活 性を有する化合物については, ALP 活性を指標に ラット骨髄由来間葉系幹細胞の骨芽細胞分化に対す る効果を確認した。ささらに閉経後骨粗鬆症モデル動 物として繁用されている卵巣摘除（ovariectomized; OVX）雌性 F344 ラットに被験化合物を 8 週間にわ たり反復経口投与し，血中骨型 ALP 活性を測定し

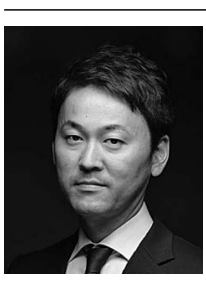

北尾達哉
京都薬品工業株式会社 取締役 研究開 発本部長. 1981 年京都府生まれ。大阪 大学大学院薬学研究科博士後期課程修 了 博士 (薬学), 金沢大学研究員, 八一 バード大学 Research Fellowを経て, 現在に至る. 

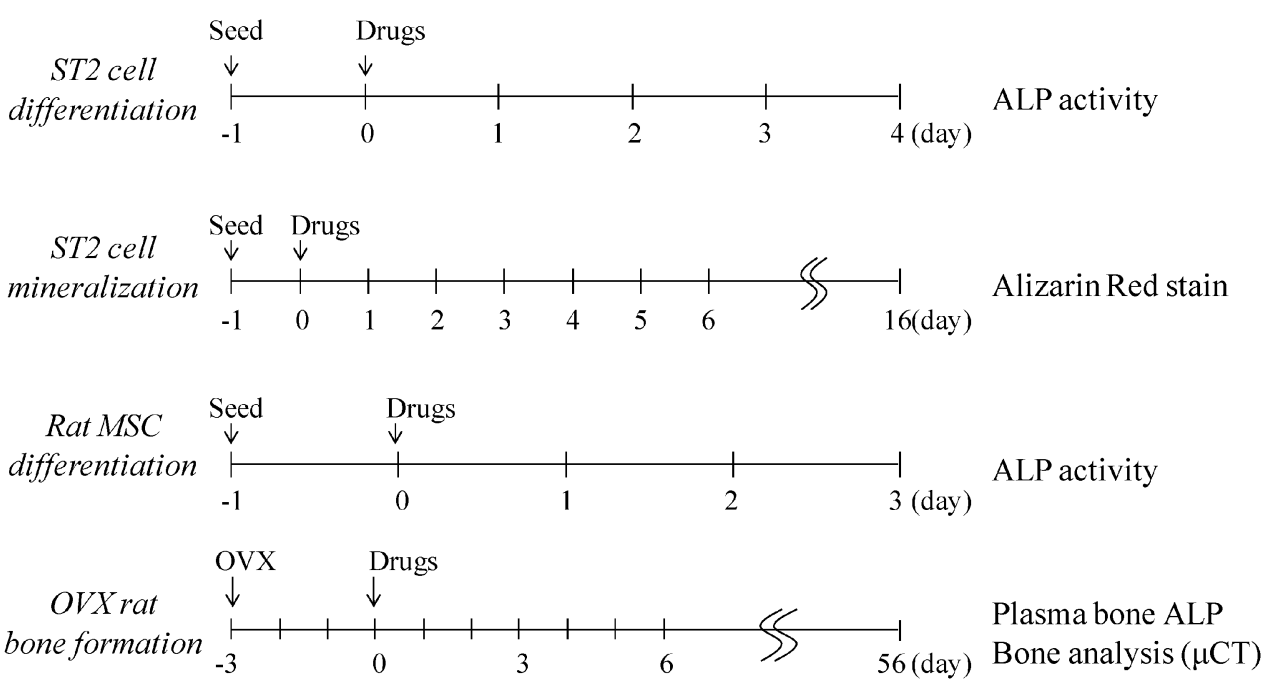

Fig. 2. Protocol of in Vitro and in Vivo Experiments

た.また，投与前及び 8 週間投与後に実験動物用 $\mu \mathrm{CT}$ （リガク）を用いて撮影し，骨形態パラメータ 変化を計測した。

\section{KY-065 の作用と代謝}

約 1000 化合物についてスクリーニングを行い, 優れた骨形成促進作用を有するフェノキシフェノー ル誘導体 KY-065 を見い出した。 KY-065 は ST2 細 胞における 4 日間処置で，10 $\mathrm{nM}$ から ALP 活性を 有意に増加させた。また，16 日間処置で $100 \mathrm{nM}$ から ST2 細胞の石灰化を促進した [Fig. 3(A)]. さらに，OVX ラットにおいて， $3 \mathrm{mg} / \mathrm{kg}$ から血中 骨型 ALP 活性並びに大腿骨骨端部の皮質骨体積を 有意に増大させ $[$ Fig. 3(B)]， シミュレーションに よる骨強度を有意に増加させた。なお， $10 \mathrm{mg} / \mathrm{kg}$ で骨髄体積を増加させる傾向を示したが，有意差は みられず，海綿骨には影響しなかった。これらの結 果から，KY-065 は骨䯣腔を狭小化することなく皮 質骨を増加させ，骨強度を増す新たな骨形成促進薬 として期待される.

次に, 雌性 SD ラットを用いて, 経口吸収性と代 謝物の検討を行った。KY-065 は $10 \mathrm{mg} / \mathrm{kg}$ 単回経 口投与において良好な経口吸収性を示し， $\mathrm{C}_{\max }$, AUC 及び $\mathrm{T}_{1 / 2}$ はそれぞれ $1.09 \pm 0.39 \mu \mathrm{M}, 1.80 \pm$ $0.18 \mu \mathrm{M} \cdot \mathrm{h}$ 及び $2.91 \pm 1.22 \mathrm{~h}$ であった。 KY-065 の $\mathrm{C}_{\max }$ は, ST2 細胞における ALP 活性増加濃度の 約 100 倍, 石灰化促進濃度の約 10 倍に達した。 OVX ラットにおいても，同様の結果が得られてい る。なお，雌性 SD ラットにおいて，KY-065 投与
後，KY-065 より高濃度で推移する代謝物（M1）の 存在を認めた。この代謝物 $\mathrm{M} 1$ の $\mathrm{C}_{\max }, \mathrm{AUC}$ 及び $\mathrm{T}_{1 / 2}$ はそれぞれ $1.40 \pm 0.30 \mu \mathrm{M} ， 3.57 \pm 0.34 \mu \mathrm{M} \cdot \mathrm{h}$ 及び $5.10 \pm 1.98 \mathrm{~h}$ であった。 M1 は，KY-065 のア セチル側鎖のカルボニル基が還元された構造を有し, ST2 細胞においてほとんど活性を示さなかった. KY-065 は血中に移行後, カルボニル還元酵素など により速やかに不活性代謝物に変換されるものと考 えられた [Fig. 4(A)].

\section{KY-273 の作用と薬物動態}

KY-065 の不活性代謝物 M1 の光学異性体である KY-273 はST2 細胞において $100 \mathrm{nM}$ から著明に ALP 活性を増加させ， $1 \mu \mathrm{M}$ から有意に石灰化を促 進した。さらに，ラット骨髄由来間葉系幹細胞初代 培養系において $100 \mathrm{nM}$ から ALP 活性を増加させ た [Fig. 4(B)]。これらの結果から，KY-273 は強 力な骨芽細胞分化・石灰化作用を有することが明ら かになった.

次に，KY-273 の骨芽細胞以外の細胞分化に対す る影響を検討した。KY-273 は，破骨細胞分化 （RAW264.7 細胞）や脂肪細胞分化（3T3-L1 細胞） にはほとんど影響せず，筋線維芽細胞分化（C2C12 細胞）及び前軟骨細胞分化（ATDC5 細胞）をわず かに促進した。 以上から，KY-273 は間葉系幹細胞 の骨芽細胞分化を促進し，骨芽細胞以外の細胞への 分化にはほとんど影響しないことが明らかになった。

KY-273 は OVX ラットにおいて， $3 \mathrm{mg} / \mathrm{kg}$ から 血中骨型 ALP 活性並びに大腿骨骨幹部の皮質骨体 


\section{(A) ST2 cell}

ALP activity

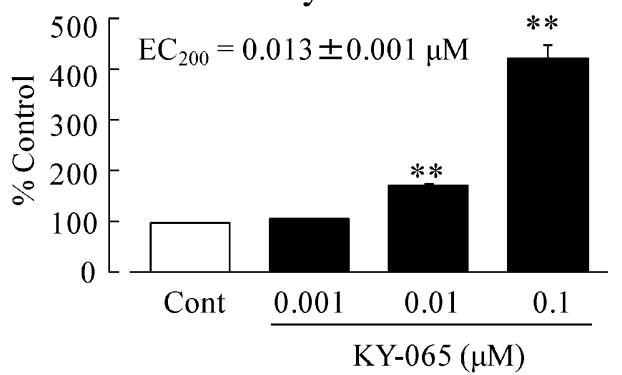

Mean士S.E.M. $(n=3), * P<0.05, * * P<0.01$

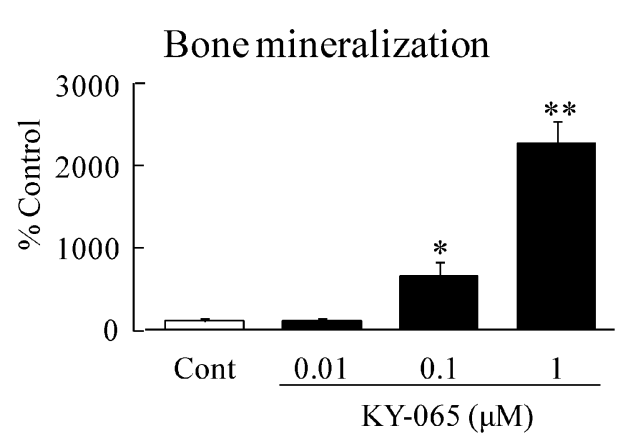

(B) OVX rat, p.o., 8 weeks
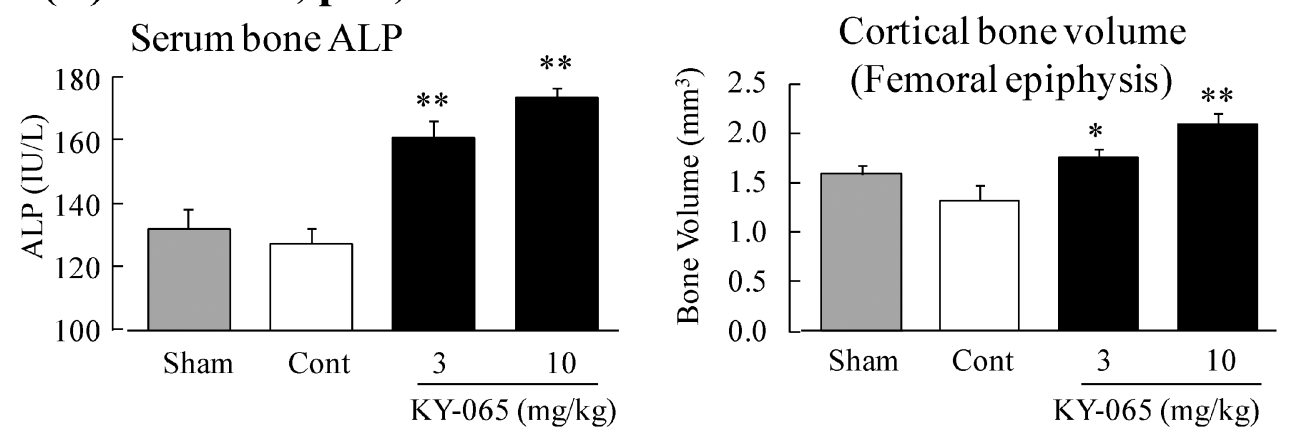

Mean \pm S.E.M. $(\mathrm{n}=8), * \mathrm{P}<0.05, * * \mathrm{P}<0.01$

Fig. 3. In Vitro and in Vivo Effects of KY-065

(A) Chemical structure of KY-065, M1 and KY-273

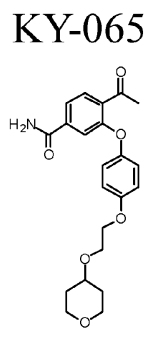

(B) Effects of KY-273

ST2 cell

ALP activity

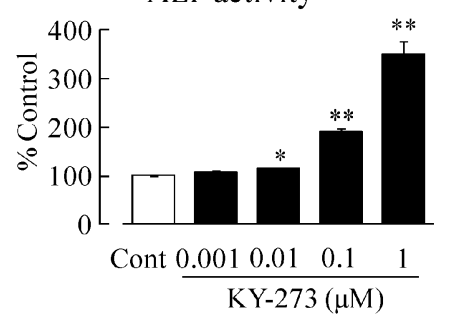

Mean \pm S.E.M. $(n=4)$

$* \mathrm{P}<0.05$, ** $\mathrm{P}<0.01$
M1

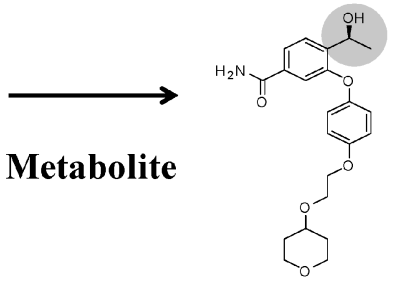

$\mathrm{EC}_{200}>10 \mu \mathrm{M}$

(inactive)
KY-273

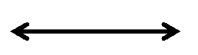

Isomer

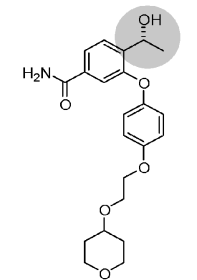

$\mathrm{EC}_{200}=0.132 \mu \mathrm{M}$

rat MSC

Bone mineralization

ALP activity

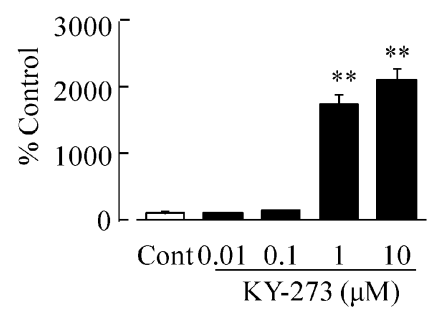

Mean \pm S.E.M. $(\mathrm{n}=4)$

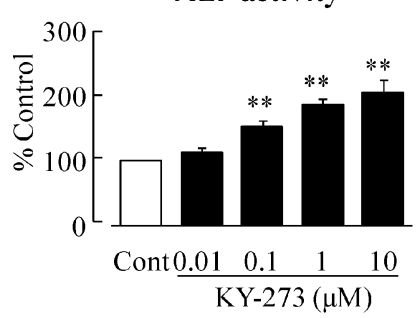

Mean \pm S.E.M. $(n=5)$

Fig. 4. Chemical Structure and in Vitro Effects of KY-273 
(A) Plasma marker

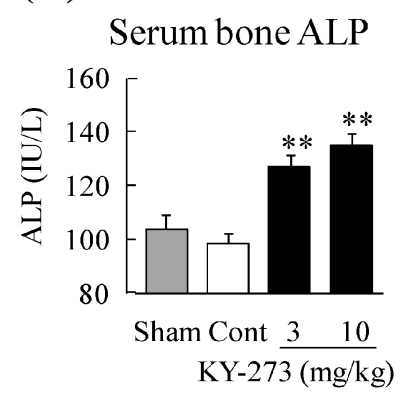

(B) Femoral diaphysis $(\mu \mathrm{CT})$

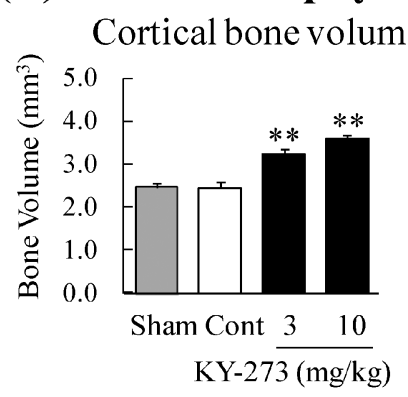

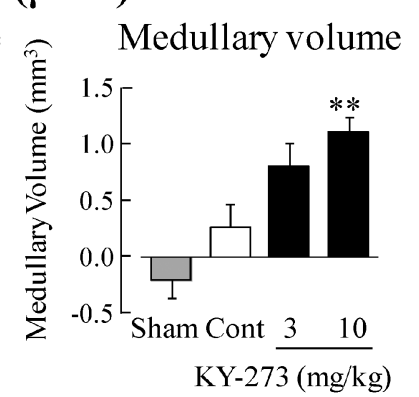

\section{(C) Femoral epiphysis $(\mu \mathrm{CT})$}
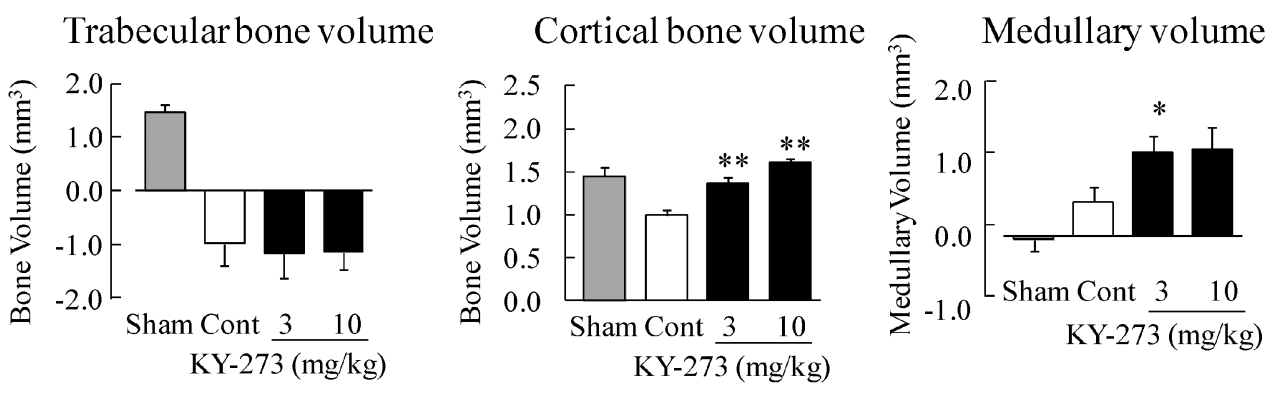

Mean士S.E.M. $(\mathrm{n}=8),{ }^{*} \mathrm{P}<0.05, * * \mathrm{P}<0.01$

Fig. 5. Effects of KY-273 on Plasma Marker and Bone Parameters in OVX Rat

積を有意に増大させ $[$ Figs. 5(A) and (B)]，シミュ レーションによる骨強度及び骨外径を有意に増加さ せた。なお， $10 \mathrm{mg} / \mathrm{kg}$ で有意に骨髄体積を増加さ せた [Fig. $5($ B) $]$ 。さらに, $3 \mathrm{mg} / \mathrm{kg}$ から大腿骨骨 端部の皮質骨体積を有意に増大させたが，海綿骨に は有意な影響を与えず $[\mathrm{Fig} .5(\mathrm{C})]$ ， シミュレー ションによる骨強度及び骨外径を有意に増加させ た。これらの結果から，KY-273 は，in vitroにお ける骨芽細胞分化促進作用は KY-065 よりやや弱い ものの，OVX ラットでは，同等以上の骨形成促進 作用を有することが明らかになった。

続いて, KY-273 の雌性 SD ラット及び雄性カニ クイザルにおける経口吸収性を検討した。KY-273 はラットにおいて，線形的で良好な経口吸収性を示 し, $10 \mathrm{mg} / \mathrm{kg}$ における $\mathrm{C}_{\max }, \mathrm{AUC}$ 及び $\mathrm{T}_{1 / 2}$ はそれ ぞれ $3.51 \pm 0.19 \mu \mathrm{M}, 7.07 \pm 1.33 \mu \mathrm{M} \cdot \mathrm{h}$ 及び 3.03 $\pm 2.50 \mathrm{~h}$ であった。 カニクイザルにおける $30 \mathrm{mg} /$ $\mathrm{kg}$ 投与後の $\mathrm{C}_{\max }$ 及び AUC はそれぞれ $4.33 \mu \mathrm{M}$ 及 び $11.2 \mu \mathrm{M} ・ \mathrm{~h}$ であった。 また，雌性ラットにおい て, KY-065（ $\mathrm{C}_{\max } 0.394 \pm 0.144 \mu \mathrm{M} ）$ 並びに極低濃 度の M1 が認められた。これは，KY-273 が酸化的 代謝により KY-065 に変換され，ついで M1 に代謝 されたものと推定される。 なお，ラット及びカニク
イザルにおける $\mathrm{C}_{\max }$ は， $\mathrm{ST} 2$ 細胞及びラット骨髄 由来間葉系幹細胞における有効濃度のそれぞれ約 35 倍及び 40 倍に達した。

\section{KY-273 の作用特性及び機序}

KY-273 と臨床で使用されているビスホスホネー ト（アレンドロネート）及び PTH 製剤テリパラチ ドの OVX ラットにおける骨形成促進作用を比較し た。前述のように，KY-273 は OVX ラットにおい て $3 \mathrm{mg} / \mathrm{kg}$ から著明に血中骨型 ALP 活性を増加さ せ大腿骨骨幹部及び骨端部の皮質骨体積，骨髄体積 及び骨強度を増加させたが，骨端部の海綿骨体積は 増加させなかった。一方，骨吸収抑制剂アレンドロ ネートは，KY-273 と異なり皮質骨体積及び骨髄体 積を増加させず，海綿骨体積を有意に増加させた [Fig. 6(A) ]。ささに，骨形成促進剂である PTH は，海綿骨及び皮質骨を増加させ，骨骾体積を減少 させた [Fig. 6(B)]。強力な骨形成促進剂は，内側 への骨形成による骨髄腔や頭蓋内腔圧迫が懸念され る. KY-273 は骨内径及び骨外径をいずれも増加さ せ，骨を内側ではなく外側に増加させることが明ら かになった，KY-273 は既存の薬剤とは異なる作用 機序により骨形成促進作用を示すと考えられる.

骨芽細胞分化には種々の転写因子が関与している. 


\section{(A) Alendronate, p.o., 8 weeks}

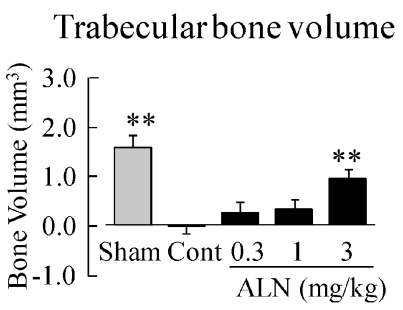

(B) PTH, s.c., 8 weeks

Trabecular bone volume

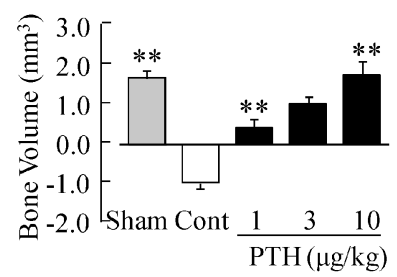

Mean \pm S.E.M. $(\mathrm{n}=8),{ }^{*} \mathrm{P}<0.05, * * \mathrm{P}<0.01$
Cortical bone volume

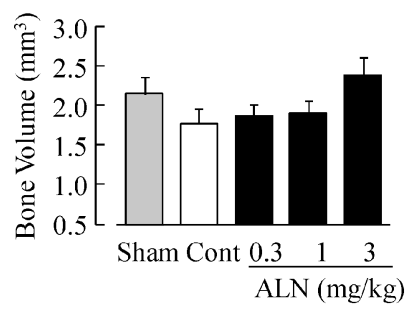

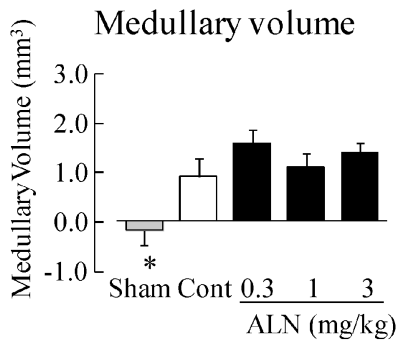

Fig. 6. Effects of Alendronate and PTH on Bone Parameters of Femoral Epiphysis in OVX Rats

KY-273 はこれらの転写因子に作用することで骨芽 細胞分化を促進しているものと考えられる．近年, 転写調節における cyclin-dependent kinase 8 （CDK8）の役割が注目され，種々の細胞において 転写促進的ないし抑制的役割を果たしていることが 明らかになっている。10) そこで，KY-273の CDK8 阻害作用を検討した。KY-273 は CDK7 及び CDK9 活性にはほとんど影響せず，CDK8 及び CDK19 を 強力に阻害した $\left(\mathrm{IC}_{50}=22 \mathrm{nM}\right.$ 及び $\left.47 \mathrm{nM}\right)$ 。さら に，KY-273 は CDK ファミリーを含む 39 種のセリ ンスレオニンキナーゼ活性にはほとんど影響せず, 選択的 CDK8/19 阻害作用を有することが明らかに なった。CDK8 とCDK19 は，高い相同性を示す木 モログであり，メディエーター複合体を形成するこ とにより，RNA polymerase II を介した転写を制御 することが知られている. ${ }^{11,12)}$

KY-273 及び類縁化合物の ST2 細胞における $\mathrm{ALP}$ 増大活性（ $\mathrm{EC}_{200}$ 值）と CDK8 阻害活性（ $\mathrm{IC}_{50}$ 値）は，正に相関することが明らかになった（ $\mathrm{R}^{2}=$ 0.8532)。また，ST2 細胞において， siRNAによる CDK8 mRNA のノックダウンは，ALP 活性を有意 に増加させた。一方，CDK19 のノックダウンは ALP 活性にほとんど影響しなかった。

以上より，KY-273の骨芽細胞分化促進作用は
CDK8 阻害作用によることが示唆された。CDK8 は BMP, Wnt/ $\beta$-catenin, Notch シグナルに関与すると 報告されているが, ${ }^{13-15)}$ 骨芽細胞分化における役割 はいまだ明確でない，KY-273 は，骨芽細胞分化因 子の転写を負に制御している CDK8 を阻害するこ とにより，骨芽細胞分化を促進している可能性が考 えられる。

\section{7. まとめ}

今回，筆者らが目指してきた骨芽細胞分化を標的 とした新規経口骨粗鬆症治療薬の開発について紹介 した。間葉系幹細胞に直接作用し骨芽細胞分化及び 骨形成を促進する化合物の設計・合成を試み, KY-065 及び KY-273 を見い出した。 KY-273 は，従 来の骨形成促進剂とは特徵を異にし，海綿骨にはほ とんど影響せず皮質骨を外側に増大させ，骨䯣腔を 狭めることなく骨量及び骨強度を増加させることが 明らかになり，新たな骨粗鬆症治療薬として期待さ れる。 また，本研究により，CDK8 阻害が骨芽細胞 分化及び骨形成を促進することが明らかになり， CDK8 を標的とした骨形成促進薬創製の可能性が開 かれた.

利益相反 北尾達哉（京都薬品工業株式会社の 役員), 伊東佑真 (京都薬品工業株式会社の社員), 
福井正樹（京都薬品工業株式会社の社員），山本め ぐみ（京都薬品工業株式会社の社員），庄子幸倫 (京都薬品工業株式会社の社員), 武田滋充（京都薬 品工業株式会社の社員), 白波瀬弘明（京都薬品工 業株式会社の役員).

\section{REFERENCES}

1) WHO, World Health Organ. Tech. Rep. Ser., 843, 1-129 (1994).

2) Osteoporos Int., 7, 1-6 (1997).

3) Iñiguez-Ariza N. M., Clarke B. L., Maturitas, 82, 245-255 (2015).

4) Makras P., Delaroudis S., Anastasilakis A. D., Metabolism, 64, 1199-1214 (2015) .

5) Harsløf T., Langdahl B. L., Curr. Opin. Pharmacol., 28, 38-42 (2016).

6) Manolagas S. C., Jilka R. L., N. Engl. J. Med., 332, 305-311 (1995).

7) Garg P., Mazur M. M., Buck A. C., Wandtke M. E., Liu J., Ebraheim N. A., Orthop. Surg., 9, 13-19 (2017).

8) Ruggiero S. L., Mehrotra B., Rosenberg T. J., Engroff S. L., J. Oral. Maxillofac. Surg., 62, 527-534 (2004).

9) Saag K. G., Petersen J., Brandi M. L., Karaplis A. C., Lorentzon M., Thomas T., Maddox J., Fan M., Meisner P. D., Grauer A., N. Engl. J. Med., 377, 1417-1427 (2017) .
10) Galbraith M. D., Donner A. J., Espinosa J. M., Transcription, 1, 4-12 (2010) .

11) Clark A. D., Oldenbroek M., Boyer T. G., Crit. Rev. Biochem. Mol. Biol., 50, 393-426 (2015) .

12) Pelish H. E., Liau B. B., Nitulescu I. I., Tangpeerachaikul A., Poss Z. C., Da Silva D. H., Caruso B. T., Arefolov A., Fadeyi O., Christie A. L., Du K., Banka D., Schneider E. V., Jestel A., Zou G., Si C., Ebmeier C. C., Bronson R. T., Krivtsov A. V., Myers A. G., Kohl N. E., Kung A. L., Armstrong S. A., Lemieux M. E., Taatjes D. J., Shair M. D., Nature, 526, 273-276 (2015).

13) Serrao A., Jenkins L. M., Chumanevich A. A., Horst B., Liang J., Gatza M. L., Lee N. Y., Roninson I. B., Broude E. V., Mythreye K., Oncogene, 37, 4792-4808 (2018) .

14) Firestein R., Bass A. J., Kim S. Y., Dunn I. F., Silver S. J., Guney I., Freed E., Ligon A. H., Vena N., Ogino S., Chheda M. G., Tamayo P., Finn S., Shrestha Y., Boehm J. S., Jain S., Bojarski E., Mermel C., Barretina J., Chan J. A., Baselga J., Tabernero J., Root D. E., Fuchs C. S., Loda M., Shivdasani R. A., Meyerson M., Hahn W. C., Nature, 455, 547-551 (2008) .

15) Fryer C. J., White J. B., Jones K. A., Mol. Cell, 16, 509-520 (2004). 